\title{
Geochemical and Isotopic Evidence for Provenance of the Western Sea of Japan Over the Last 30000 Years
}

OPEN ACCESS

Edited by:

Davide Tiranti,

Agenzia Regionale per la Protezione

Ambientale (ARPA), Italy

Reviewed by:

Dhananjay Anant Sant,

Maharaja Sayajirao University

of Baroda, India

LiWu,

Anhui Normal University, China

${ }^{*}$ Correspondence:

Jianjun Zou

zoujianjun@fio.org.cn

Xuefa Shi

xfshi@fio.org.cn

Specialty section:

This article was submitted to

Quaternary Science, Geomorphology

and Paleoenvironment,

a section of the journal

Frontiers in Earth Science

Received: 05 December 2020

Accepted: 04 March 2021

Published: 31 March 2021

Citation:

Dou R, Zou J, Shi X, Zhu A,

Dong Z, Gorbarenko S, He L, Gao J,

Zhang Y and Cui J (2021)

Geochemical and Isotopic Evidence for Provenance of the Western Sea

of Japan Over the Last 30000 Years.

Front. Earth Sci. 9:638178.

doi: 10.3389/feart.2021.638178

\begin{abstract}
Ruxi Dou ${ }^{1}$, Jianjun Zou',2*, Xuefa Shi,2*, Aimei Zhu',2, Zhi Dong ${ }^{1,2}$, Sergey Gorbarenko ${ }^{3}$, Lianhua $\mathrm{He}^{1,2}$, Jingjing $\mathrm{Gao}^{1,2}$, Ying Zhang ${ }^{1,2}$ and Jingjing Cui ${ }^{1,2}$

${ }^{1}$ Key Laboratory of Marine Geology and Metallogeny, First Institute of Oceanography, Ministry of Natural Resources, Qingdao, China, ${ }^{2}$ Laboratory for Marine Geology and Environment, Pilot National Oceanography Laboratory for Marine Science and Technology (Qingdao), Qingdao, China, ${ }^{3}$ V.I. Il'ichev Pacific Oceanological Institute, Far East Branch of the Russian Academy of Sciences, Vladivostok, Russia
\end{abstract}

The Sea of Japan (JS) is a unique marginal sea in the western North Pacific that is characterized by four shallow straits. It can provide information about the paleoenvironment, for instance indicating variations in the East Asian Monsoon, Tsushima Warm Current, sea ice coverage, and Westerly Jet. Compared with other marginal seas in the western North Pacific, the JS is currently the only marginal sea without influx from large rivers. It is, therefore, of interest to determine the source of terrigenous sediments over time, particularly in the western JS, which has been less investigated in previous reports. In this study, a suite of multi-proxies including $\mathrm{Sr}$ and $\mathrm{Nd}$ isotopes and minor elements were measured for fine fractions $(<63 \mu \mathrm{m})$ of core LV5318-2 that were recovered from the western JS over the last $30 \mathrm{ka}$. Our results show that the sediments are rich in volcanic detritus and that the provenance of terrigenous sediments in the western JS is mainly derived from the arid region in northern China and coastal areas in the Far East. During the Last Glacial Maximum, the increased coverage of sea ice may have contributed to the accumulation of terrigenous debris. Meanwhile, the stronger East Asian Winter Monsoon and expansion of the Westerly Jet over northern China also carried more dust to the study area. However, the weakened atmospheric circulation and rise in sea level, induced by the ascending boreal insolation during the last deglaciation and early Holocene, remarkably reduced input of terrigenous debris, and the intense melting of sea ice delivered an amount of detritus from coastal areas to the research area. After $8 \mathrm{ka}$, the high stand sea level and opening of the Tatar Strait may have led to the development of the Liman Cold Current, which transports large quantities of volcanic materials to the study area continuously and produces more positive Eu anomalies, radiogenic $\varepsilon \mathrm{Nd}$, and depleted $\Sigma \mathrm{REE}$.

Keywords: Sr-Nd isotopes, minor elements, sea level, the Liman Cold Current, the Sea of Japan, sediment provenance discrimination

\section{INTRODUCTION}

Climate teleconnection at different latitudes has led to the evolution of the global paleoclimate (Porter and An, 1995; Wang et al., 2005). Marginal seas in the Northwest Pacific are affected by drivers such as the Siberian High, East Asian Monsoons (EAM), $\mathrm{CO}_{2}$, and El Niño-Southern Oscillation to varying degrees. Thus, the Northwest Pacific is an ideal area to study the coupling 
and interaction between polar and tropical/subtropical climates (Wang, 1999; Nürnberg and Tiedemann, 2004; Zhang et al., 2019; Zhao et al., 2019; Wu et al., 2020). The Sea of Japan (JS), one of these marginal seas (Figure 1), is overlain by thick sediments deposited over dozens of millions of years (Tada et al., 2018). Previous research has revealed the influence of the East Asian tectonic activity, solar radiation, and sea-level changes on its sedimentation over longer timescales (Tada, 1994; Nagashima et al., 2007a; Shen et al., 2017; Zhang et al., 2018), and also indicates that the EAM and ocean current led to the paleoenvironmental evolution of the JS at shorter timescales (Itaki et al., 2004; Ikehara and Fujine, 2012). Thus, more detailed research on JS will help to develop our understanding of the evolution of the climate and environmental system of East Asia.

As a critical part of the East Asian source-to-sink processes, the detrital materials in the JS mainly originate from the East Asian continent and the Japan Arc (Mahoney, 2005). Previous studies have confirmed various styles of detritus input, including atmospheric circulation, ocean currents, rivers, sea ice, and volcanic eruptions (Irino and Tada, 2000; Ikehara, 2003; Chun et al., 2007; Zou et al., 2012; Um et al., 2013; Xu et al., 2014; Zou et al., 2021). There are several dust records in the southern, centeral, and eastern JS, and the southward/northward shift of the Westerly Jet (WJ) was reconstructed by grain-size and mineralogy proxies (Nagashima et al., 2007a; Dong et al., 2017; Shen et al., 2017). A large amount of suspension from the East China Sea, which is delivered by the Yangtze and Yellow Rivers from the continent and the Kuroshio Current from Taiwan Island, was transported to the JS by the Tsushima Warm Current (TWC), resulting in fewer radiogenic sediments in the southwest basin (Zou et al., 2012; Xu et al., 2014; Zou et al., 2021). In the continental shelf area flowing out Japanese rivers and the Nakdong River, the sediments show significant evidence of being affected by materials from the island arc and the Korean Peninsula (Nagashima et al., 2007b; Um et al., 2013). Seasonal sea ice is formed in modern wintertime in the western JS due to the cold wind from Siberia. It expands southward from Marine Isotopic Stage (MIS) 5 to the Last Glacial Maximum (LGM) owing to global cooling with significant fluctuation, which may be related to millennium cold events triggered by the North Atlantic meltwater (Ikehara, 2003; Ikehara and Fujine, 2012). However, systematic understanding of the provenance and evolution of JS is still limited owing to the lack of research on the western JS compared with the southern and eastern JS.

Under the influence of the Liman Cold Current (LCC) and the formation area of the Japan Sea Proper Water, the western JS sediments recorded the growth and decay of sea ice and evolution of the EAM (Gorbarenko et al., 2014; Shi et al., 2019; Dou et al., 2020; Dong et al., 2021). Sea-ice coverage expanded southward significantly during the LGM and melted intensely as a result of boreal insolation rising during the Last Deglaciation (Ikehara, 2003). The formation of modern LCC is related to melting ice from the north, which is influenced by the fresh water input from the Amur River (Martin and Kawase, 1998; Park et al., 2006; Nihashi et al., 2017). A subpolar front occurs because of the confluence of the TWC and the LCC, contrasting the hydrology and climatology between the two sides (Park et al., 2007; Kim et al., 2008). However, information about the formation and evolution of LCC is scarce.

This study presents minor elements (Th, Zr, Cr, Sc), rare earth elements (REE), and Sr-Nd isotope records of core LV53-18-2 recovered from the western JS. The study aimed to reconstruct changes in relatively high-resolution sediment provenance and to examine the roles of atmospheric circulation, sea level fluctuation, and LCC in regulating terrigenous sediment input into the study area over the last $30 \mathrm{ka}$.

\section{MATERIALS AND METHODS}

The $393 \mathrm{~cm}$ sediment core LV53-18-2 characterized as grayishgreen to grayish brown fine silt was retrieved from the western slope of JS $\left(42^{\circ} 56^{\prime} \mathrm{N}, 134^{\circ} 44^{\prime} \mathrm{E}, 551 \mathrm{~m}\right.$ depth) during the first China-Russia joint cruise in 2010 (Figure 1); it was sliced into centimeter-sized slices for further analysis.

An age model for core LV53-18-2 was established based on seven optically stimulated luminescence (OSL) ages obtained from fine grain $(<38 \mu \mathrm{m})$ quartz (Figure 2). Sample preparation and luminescence measurements were carried out at the Luminescence Dating Laboratory of the Nanjing Institute of Geography and Limnology, Chinese Academy of Sciences, China. The samples were wet-sieved to obtain a fine grain component and then treated with $10 \% \mathrm{HCl}$ and $30 \% \mathrm{H}_{2} \mathrm{O}_{2}$ to remove carbonates and organic materials. According to Stokes' law, the fine grain fraction was separated and then etched in the 30\% $\mathrm{H}_{2} \mathrm{SiF}_{6}$ to obtain pure quartz for dating. The age of the core bottom was $30.03 \mathrm{ka}$ and the mean resolution was $76 \mathrm{a} / \mathrm{cm}$. More details can be found in the report by Yang et al. (2015).

The sediment rates were calculated by linear interpolation between every two dating points. The sediment rates in the last glacial period $(20.7 \mathrm{~cm} / \mathrm{ka}$ on average) were higher than those in the last deglaciation $(10.7 \mathrm{~cm} / \mathrm{ka})$ and the Holocene $(10.3 \mathrm{~cm} / \mathrm{ka}$ on average). The mass accumulation rates (MARs) of LV53-182 were calculated using the equation: $\operatorname{MAR}\left(\mathrm{g} / \mathrm{cm}^{2} / \mathrm{ka}\right)=$ linear sedimentation rates $(\mathrm{LSR}, \mathrm{cm} / \mathrm{ka}) \times$ dry bulk density $(\mathrm{DBD}$, $\mathrm{g} / \mathrm{cm}^{3}$ ) (Zou et al., 2015).

A total of 120 samples from core LV53-18-2 were analyzed for trace elements and REE by ICP-MS (Thermo Scientific $X$ SERIES 2) at the Key Laboratory of Marine Geology and Metallogeny, First Institute of Oceanography, Ministry of Natural Resources, China. The bulk sediment was treated using excess $\mathrm{HCl}(0.25 \mathrm{~N})$ and $\mathrm{H}_{2} \mathrm{O}_{2}(15 \%)$ to remove carbonate and organic materials. Approximately $50 \mathrm{mg}$ of dried and ground samples $(<63 \mu \mathrm{m})$ were dissolved in a mixture of ultrapure $\mathrm{HF}-\mathrm{HNO}_{3}$ followed by concentrated $\mathrm{HClO}_{4}$ in closed Teflon beakers and then redissolved in $5 \% \mathrm{HNO}_{3}$. A blank experiment with GSD-9 standard material and one replicate with every ten samples were used for quality control during the experimental processes. The relative standard deviations of the trace element and REE analyses were all $<5 \%$. $\delta \mathrm{Eu}$ was calculated by comparing the Eu concentration with its neighboring elements: $\delta \mathrm{Eu}=\mathrm{Eu}_{N} /\left(\mathrm{Sm}_{N} \times \mathrm{Gd}_{N}\right)^{1 / 2}$, where $\mathrm{N}$ represents the normalization of the upper continental crust (UCC) (Taylor and McLennan, 1995). 

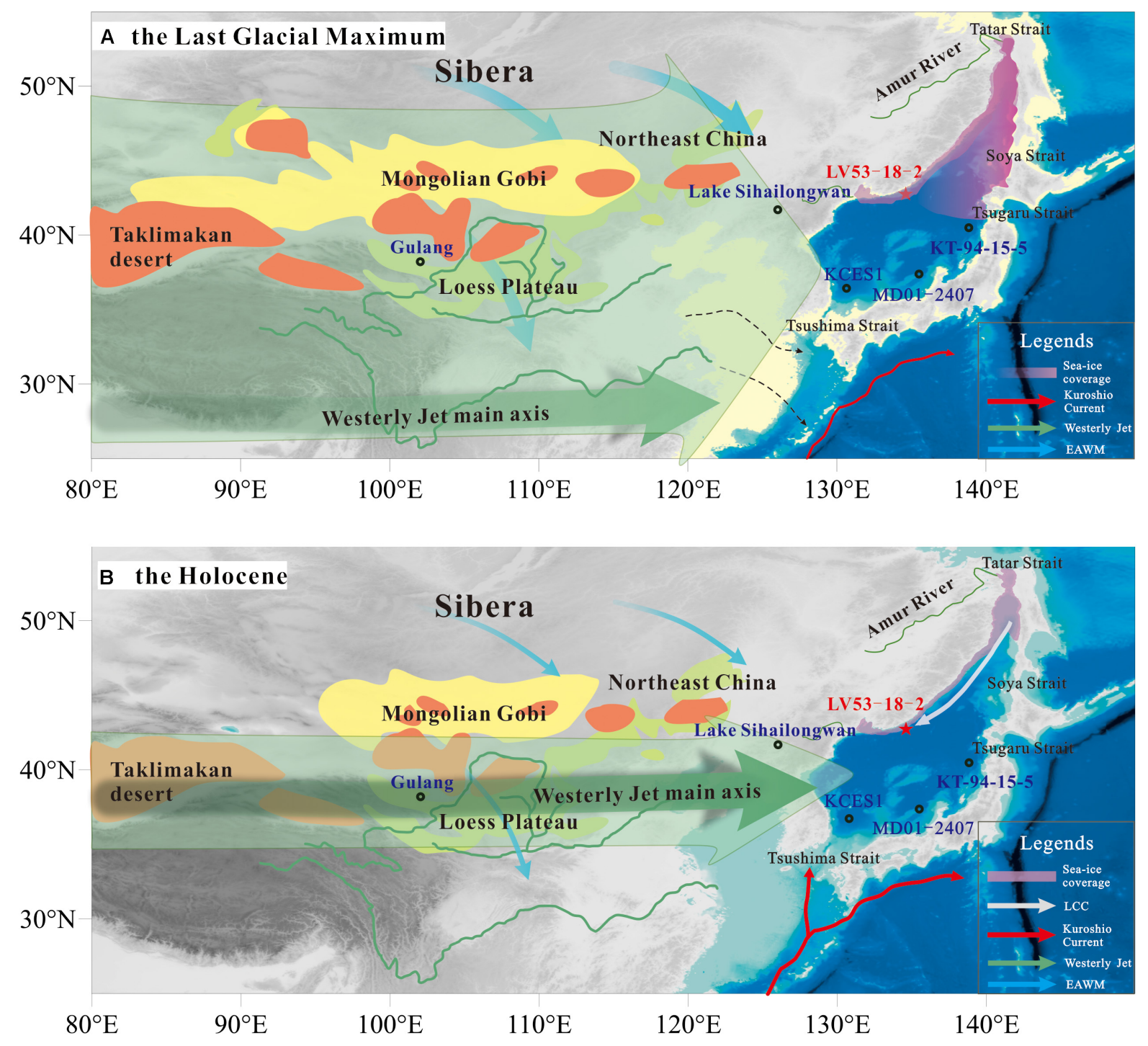

FIGURE 1 | Location map of core LV53-18-2 in the western Sea of Japan (A) during the Last Glacial Maximum (B) during the Holocene. Core KT94-15-5, MD01-2407 and KCES1 (Nagashima et al., 2007a; Zou et al., 2021) for comparison are shown in black hollow dots. Atmospheric circulation patterns, arid land over East Asian, oceanic current, and sea ice coverage influencing the Sea of Japan also are presented in this diagram which references (Nagashima et al., 2011).

The $\mathrm{Sr}$ and $\mathrm{Nd}$ isotopes of 28 samples were analyzed using MC-ICP-MS (Nu plasma) at the Key Laboratory of Marine Geology and Metallogeny, First Institute of Oceanography, Ministry of Natural Resources, China. Approximately $45 \mathrm{mg}$ of organic and carbonate-free fine fractions $(<63 \mu \mathrm{m})$ were weighed and dissolved in a mixture of ultrapure $\mathrm{HNO}_{3}+\mathrm{HF}+\mathrm{HClO}_{4}$. The $\mathrm{Sr}$ and $\mathrm{Nd}$ fractions were separated using standard ion-exchange techniques (Cao et al., 2015). The $\mathrm{Sr}$ isotopic ratios were normalized to ${ }^{86} \mathrm{Sr} /{ }^{88} \mathrm{Sr}$ $(0.1194)$ and the $\mathrm{Nd}$ isotopic ratios were normalized to ${ }^{146} \mathrm{Nd} /{ }^{144} \mathrm{Nd}(0.7219)$. Sr isotope compositions of standard NBS987 yielded ${ }^{87} \mathrm{Sr} /{ }^{86} \mathrm{Sr}=0.710261 \pm 0.000005(1 \sigma)$ (recommended value $0.710340 \pm 0.00026) ; \mathrm{Nd}$ standard JNdi gave $0.512115 \pm 0.000001(1 \sigma)$ (recommended value $0.512115 \pm 0.000007)$. For convenience, the ${ }^{143} \mathrm{Nd} /{ }^{144} \mathrm{Nd}$ ratio is expressed as $\varepsilon N d$ with the chondritic uniform reservoir value of 0.512638 (Jacobsen and Wasserburg, 1980).

\section{RESULTS}

\section{Minor Elements}

Trace elements in sediments can be affected by provenance, weathering, transportation, sorting, and diagenesis (Franzese and Hemming, 2013). Among them, REE, Zr, Th, Sc, and Cr originate from the continental crust. They were conservative and thus, usually used to trace the origin. $\mathrm{Cr}$ and $\mathrm{Sc}$ are mostly enriched in mafic/ultramafic rocks, while Th is mainly concentrated in felsic rocks (Vital and Stattegger, 2000). Th/Sc is usually used as an indicator of igneous chemical differentiation processes and the 


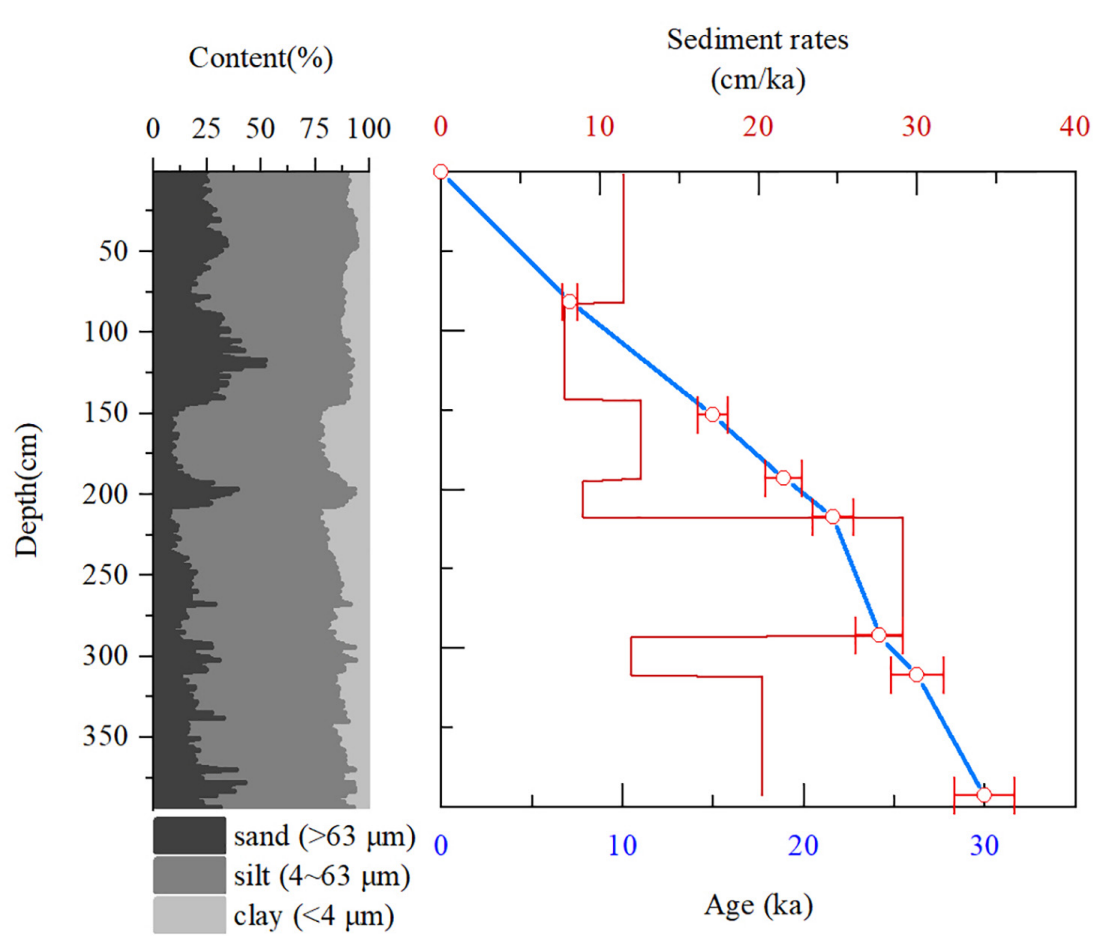

FIGURE 2 | Lithologic column profile and calendar age of LV53-18-2. The 7 OSL date samples are shown with an uncertainty of $2 \sigma$.

$\mathrm{Zr} / \mathrm{Sc}$ ratio is a useful index of zircon enrichment (McLennan et al., 1990). Figure 3A shows that detrital components are more felsic and that the $\mathrm{Th} / \mathrm{Sc}$ ratio decreases after the Holocene. This implies a shift of provenance or change in the proportion of different sources. Enrichment in zircon (high $\mathrm{Zr} / \mathrm{Sc}$ ratio) can be observed during the late last deglacial period, indicating strong hydrodynamic conditions during that time (Figure 3B).

The REE parameter depth profiles and UCC-normalized pattern of LV53-18-2 both show two-stage variations (Figures 4, 5A-D). Before the Holocene, the $\Sigma \mathrm{REE} / \mathrm{Al}_{2} \mathrm{O}_{3}$ ratio and $\Sigma$ REE concentrations remained relatively high and exhibited a similar trend. REE fractionation patterns resemble those of the Northern China desert (Xie et al., 2019) and Chinese Loess Plateau (Jahn et al., 2001) except for depleted light REE (LREE) concentrations and positive Eu anomalies (Figures 4A-F). During the Holocene, REE parameter values decreased significantly, accompanied by more depleted LREE and high REE (HREE) concentrations as well as prominent positive Eu anomalies, which are similar to the pattern of the Japan Arc (Togashi et al., 2000). The mass accumulation rates are much more lower during the Holocene than other periods while the $\mathrm{Eu}$ anomalies display opposite trend that it increases after 8 ka significantly (Figures 4G,H). The UCC-normalized results exhibit significant positive Eu anomalies of 1.0 to 1.2, from 30 to $8 \mathrm{ka}$, and of 1.3 to 1.4 after $8 \mathrm{ka}$.

\section{Nd and Sr Isotopes}

The Sr and Nd contents, together with their isotopic parameters, fluctuated before the Holocene and abruptly changed at 8 ka (Figures 4I-L). During the last glacial period, ${ }^{87} \mathrm{Sr} /{ }^{86} \mathrm{Sr}$ ratios range from 0.708164 to 0.711713 and $\mathrm{Sr}$ contents varied from 158 to $211 \mathrm{ppm}, \mathrm{Nd}$ content and $\varepsilon \mathrm{Nd}$ values changed from 19.1 to $23.7 \mathrm{ppm}$ and -4.9 to -3.6 respectively. During the deglacial period, the ${ }^{87} \mathrm{Sr} /{ }^{86} \mathrm{Sr}$ ratios and $\mathrm{Nd}$ content decreased slightly, $\mathrm{Sr}$ content and $\varepsilon \mathrm{Nd}$ increase a bit. During the Holocene, ${ }^{87} \mathrm{Sr} /{ }^{86} \mathrm{Sr}$ ratios ranged from 0.706346 to 0.708265 , and $\mathrm{Sr}$ contents varied from 193 to $289 \mathrm{ppm}$. The $\varepsilon \mathrm{Nd}$ values show an increasing trend from -4.5 to -2.5 .

\section{DISCUSSION}

\section{Variations in REEs and Sr-Nd Isotope Ratios}

REEs have been well accepted as reliable provenance tracers because they behave conservatively (Taylor and McLennan, 1995). As mentioned above, many factors including parent rock composition, grain size, mineralogy, and weathering are responsible for REE compositions (Yang et al., 2002). In this study, samples were treated with excess $\mathrm{HCl}$ and $\mathrm{H}_{2} \mathrm{O}_{2}$ to remove carbonate and organic matter. Therefore, the residual fractions represented the siliciclastic fraction of the core. Poor correlations between $\Sigma$ REE, mean grain size, and $\mathrm{MnO}$ concentration are observed, demonstrating that the sediment grain size and sedimentary redox conditions are not important 

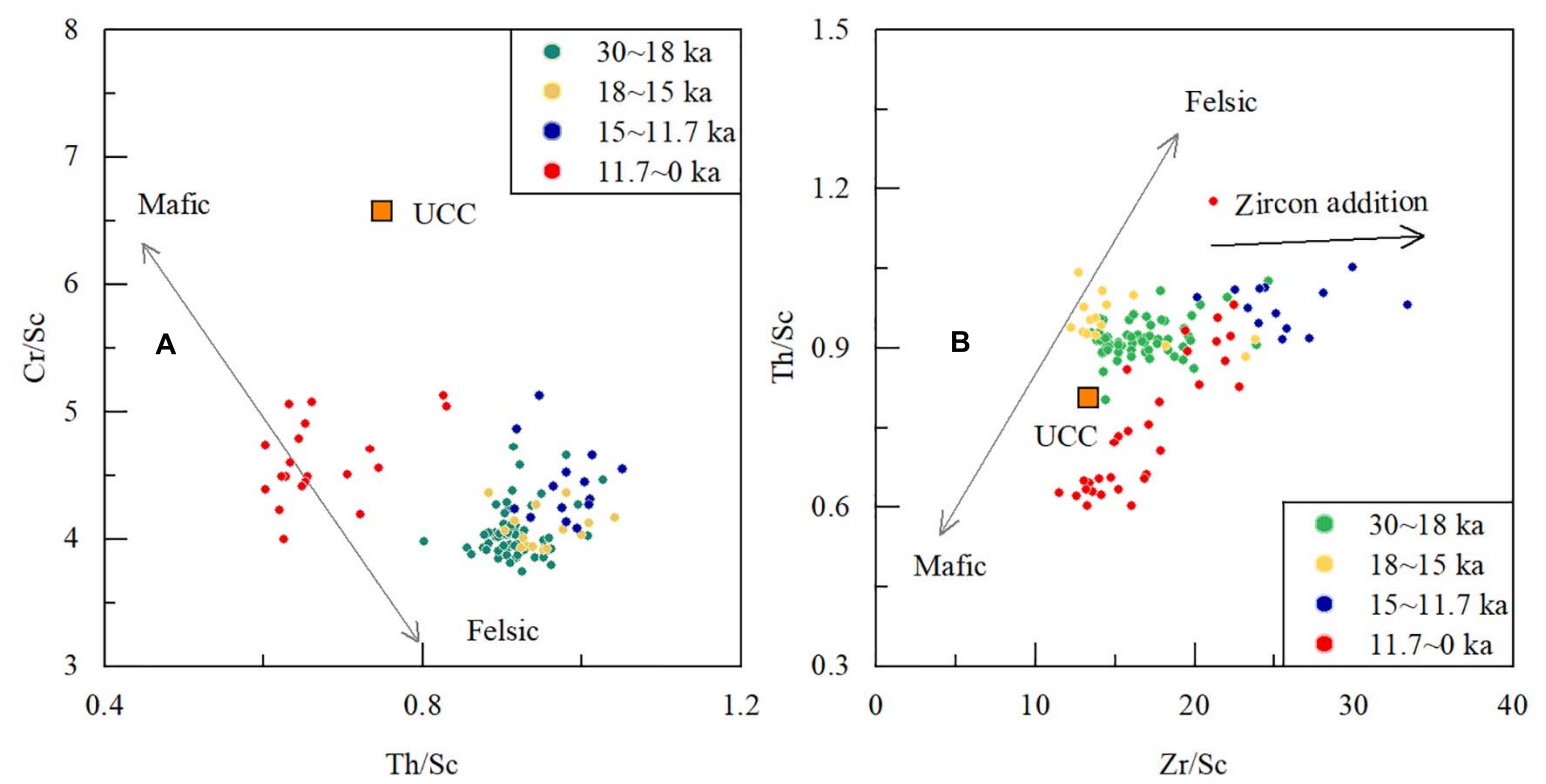

FIGURE 3 | Evaluation of sedimentary provenance and sorting by plots of (A) Th/Sc-Cr/Sc and (B) Th/Sc-Zr/Sc.

factors in controlling the REE concentrations in our samples (Figures 4M, 6A,B).

$\mathrm{Sr}-\mathrm{Nd}$ isotopic compositions of sediments are effective proxies for the discrimination of their provenance (Mclennan et al., 1993). The Sr isotope ratios of detrital materials are often influenced by grain size due to varying mineralogy. Fine grained fractions tend to be enriched in radiogenic ${ }^{87} \mathrm{Sr}$ because clay minerals (such as micas and biotite) tend to have high $\mathrm{Rb} / \mathrm{Sr}$ ratios (Walter et al., 2000). In contrast, the $\mathrm{Nd}$ content is barely affected by superficial geochemical processes and inherits the characteristics of provenance, which makes it an excellent tool for the reconstruction of provenance in sediments (Goldstein et al., 1984; Grousset et al., 1988). To further explore the factors influencing the $\mathrm{Sr}$ isotopes, we plotted the correlation between ${ }^{87} \mathrm{Sr} /{ }^{86} \mathrm{Sr}, \mathrm{Rb} / \mathrm{Sr}$, and silt mean size, as shown in Figures 7A,B. $\mathrm{The} \mathrm{Rb} / \mathrm{Sr}$ ratio may reflect the chemical weathering of sediment because $\mathrm{Sr}$ has greater mobility than $\mathrm{Rb}$. This usually leads to a high $\mathrm{Rb} / \mathrm{Sr}$ ratio when chemical weathering intensity is enhanced. A strong positive correlation coefficient $\left(\mathrm{R}^{2}=0.88\right)$ between $\mathrm{Rb} / \mathrm{Sr}$ and $\mathrm{Sr}$ isotopic ratios indicates that the weathering effect on ${ }^{87} \mathrm{Sr} /{ }^{86} \mathrm{Sr}$ is dominant. A moderate correlation $\left(\mathrm{R}^{2}=0.36\right)$ was observed between ${ }^{87} \mathrm{Sr} /{ }^{86} \mathrm{Sr}$ and silt mean size, implying that grain size still exerts an effect on the Sr isotopic ratio. Nevertheless, these points can be divided into three distinct clusters, and each cluster seems to have no strong correlation between ${ }^{87} \mathrm{Sr} /{ }^{86} \mathrm{Sr}$ and mean silt size. Therefore, we conclude that provenance variations instead of grain size affect the dominating ${ }^{87} \mathrm{Sr} /{ }^{86} \mathrm{Sr}$ ratio.

\section{Potential Provenance End-Members}

Previous studies have suggested that the Sino-Korean Craton is the main source area of terrigenous debris, and wind and that ocean currents are the primary transport agencies affecting the southwest JS (Nagashima et al., 2011; Zou et al., 2012; Xu et al., 2014; Shen et al., 2017; Zou et al., 2021). Nevertheless, the East Asian continent is also tectonically controlled with obvious differences in chemical compositions across different regions (Chen et al., 2007). The $\varepsilon N d$ in the arid region of Northeastern China is more positive than that in central and western China, which is the result of a collision between the Siberian Plate and the southern blocks. In central China, the China Loess Plateau, representing the weathering residual of the UCC, is characterized by low $\varepsilon N d$ and high ${ }^{87} \mathrm{Sr} /{ }^{86} \mathrm{Sr}$ ratios and controls the radiogenic properties of Yellow River sediments (Meng et al., 2008). The Yangtze River, which plays a major role in the fluxes of terrestrial material from the Chinese mainland to the western Pacific, is also affected by compositional variations among different reaches. Its $\varepsilon \mathrm{Nd}$ values gradually decrease downstream from -10.8 on average in the upper reaches to -12.3 in the lower reaches, while the ${ }^{87} \mathrm{Sr} /{ }^{86} \mathrm{Sr}$ ratios increase correspondingly (Yang S. et al., 2007). The Korea Craton can be excluded as a potential source for our core because its basement is less radiogenic $(<-15)$ compared with our records (Mahoney, 2005).

Notably, the study area is adjacent to the Sikhote-Alin orogenic belt in the Far East (Jahn et al., 2015), which can provide terrigenous materials to affect the composition of core LV53-18-2. The Sikhote-Alin orogenic belt overlaid with late Cretaceous-Paleogene volcanic rocks was composed of a JurassicLate Cretaceous accretionary prism and island arc, which were later intruded by Cretaceous granites (Grebennikov et al., 2016). Despite the complex components of it, more attention should be paid to the island arc belt along the western coast.

Compared with the Sino-Korean Craton, the Japan Arc can supply more materials to the JS directly via rivers (Milliman and Meade, 1983). The amount of detritus entering the JS through the Tsushima Strait may be less than $10 \%$ of that provided by 


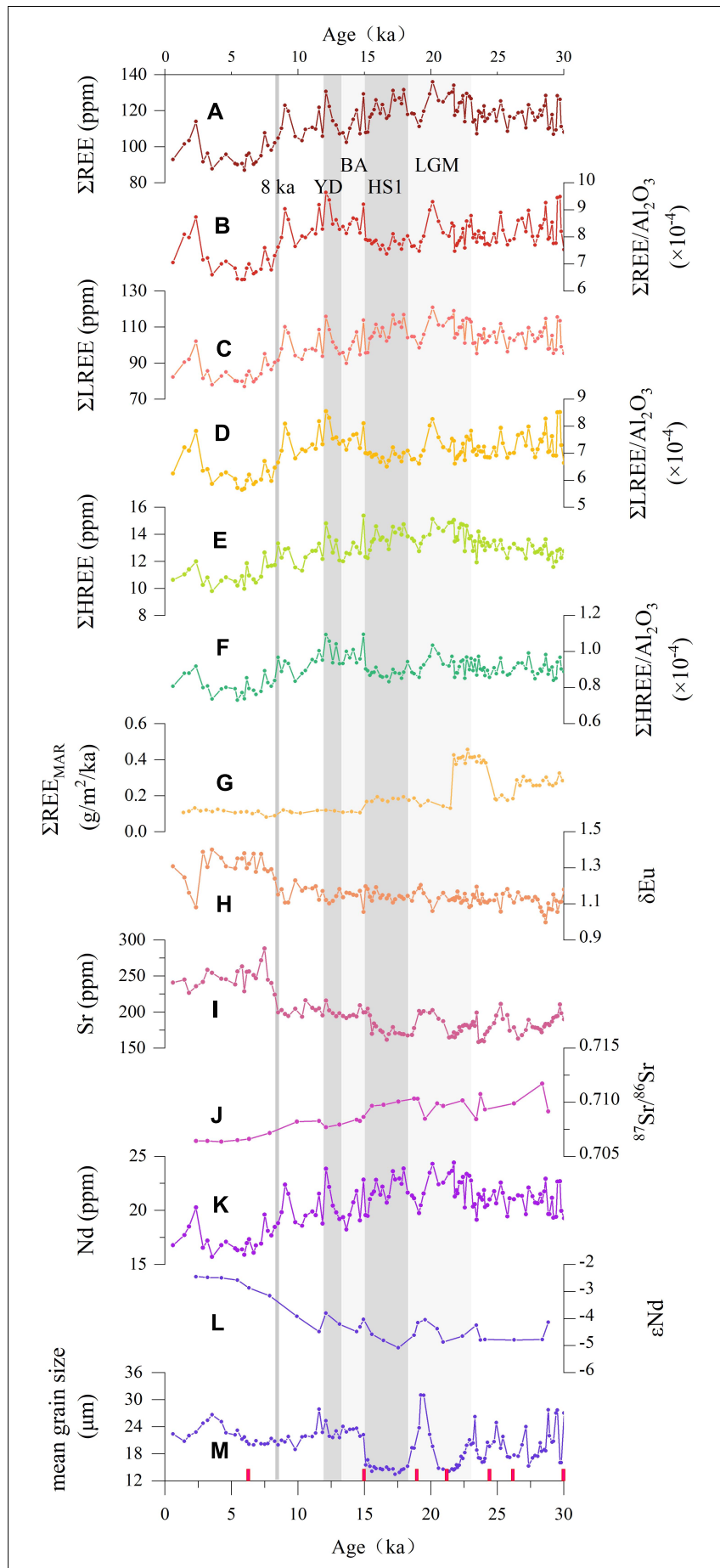

FIGURE $\mathbf{4}$ | Depth profiles of parameters of REEs (A-H), Sr-Nd (I-L), and grain size (M) in core LV53-18-2. Red rectangles denote age control points.

the Japan Arc (Irino and Tada, 2000). The $\varepsilon N d$ values of Japan crust, as well as sediments delivered by rivers on it, are more radiogenic than the Sino-Korean Craton, although the chemical compositions in the northeast and southwest Japan differ to some extent (Mahoney, 2005).
Sr-Nd isotopic records in the southwestern JS have demonstrated a dominating terrigenous detrital material from mainland China (Xu et al., 2014; Zou et al., 2021). Meanwhile, multi-proxies including grain size and the electron spin resonance of quartz at different sites have suggested that dust from East Asia also plays an important role in the sedimentation of eastern and central JS (Nagashima et al., 2007a; Nagashima et al., 2007b). Compared to southwest JS, which can receive a significant quantity of terrigenous debris by TWC and coastal rivers and thus is less affected by dust, we pay attention to aeolian input from the Northeast China Sandy Land, Chinese Loess Plateau, and even the Taklimakan desert in the western JS, considering the wind trajectory and geographical position. Moreover, the absence of large rivers along the western coast limits the riverine input to the western JS.

\section{Variations in Terrigenous Provenance Over the Last $\mathbf{3 0}$ ka}

REEs and Sr-Nd isotopes were plotted to discriminate the provenance of the terrigenous component in core LV53-18-2 (Figures 8A,B, 9A,B). All plots indicate sediment source in this core is the closest to northern China before the Holocene and approaches volcanic materials gradually after $8 \mathrm{ka}$. The main difference between these two plots is in terms of the variations in $\mathrm{Sr}-\mathrm{Nd}$ isotopes during the late glacial period and early Holocene $(15 \sim 8 \mathrm{ka})$, which is not obvious in the plot of $(\mathrm{La} / \mathrm{Sm})_{N^{-}}$ $(\mathrm{Gd} / \mathrm{Yb})_{N}$ and $(\mathrm{LREE} / \mathrm{REE})_{N}-(\mathrm{HREE} / \mathrm{REE})_{N}$. However, all the plots indicate that northern China and volcanic materials are the two main source end members.

Several provenance studies have been reported for southwestern JS using REEs and Sr-Nd isotopes (Xu et al., 2014). These suggested that terrigenous material in the southwestern JS are mainly from China mainland via the Yellow River since $21.1 \mathrm{ka}$ and that the portion from Taiwan increases after $7.2 \mathrm{ka}$. REEs provenance discrimination revealed that sediments on the slope of the Ulleung Basin are a mixture of sediments from Chinese rivers and the Nakdong River, and sedimentation was controlled by the East Asian Winter Monsoon (EAWM) and sea-level change during the last glaciation (Um et al., 2017). The latest $\mathrm{Sr}-\mathrm{Nd}$ isotope result of core KCES1 in southwestern JS further demonstrated that the terrigenous material is derived from mainland China, transported by the Yangtze and Yellow Rivers from 42 to $7 \mathrm{ka}$, and dominated by Yangtze river-derived sediments after $7 \mathrm{ka}$ (Zou et al., 2021; Figure 9B). Compared to the reports mentioned above, our records do not reflect the importance of Chinese rivers but emphasize the role of atmospheric circulation (the EAWM and Westerly Jet) in sediment transportation, implying that Chinese rivers can barely affect sedimentary processes in the western JS. Furthermore, it is likely to be an intrinsic correlation of provenance change during the middle Holocene between the western and southwestern JS because the source change occurred at about 8-7 ka. This should be investigated in detail in a further study.

Volcanic material and northern China were chosen as end members to plot the mixing line aiming to quantitatively assess their relative contributions. Figure 9B shows that the volcanic 


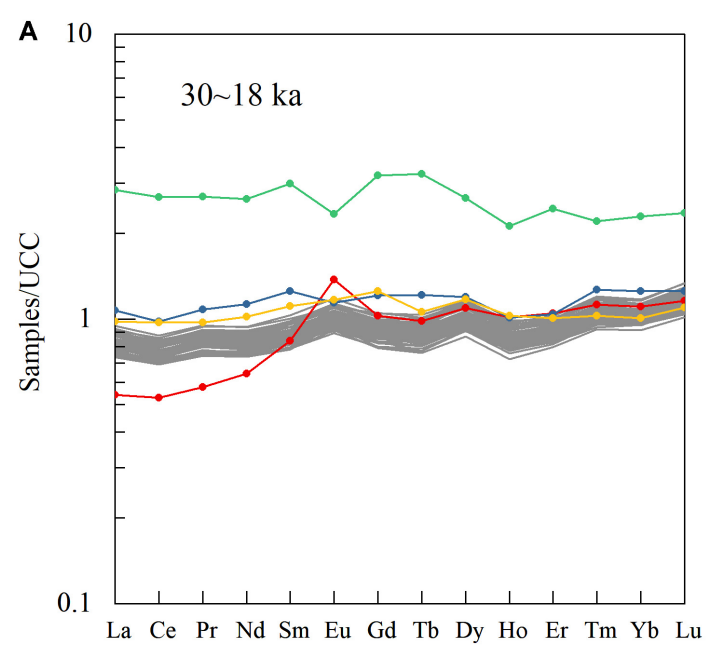

C

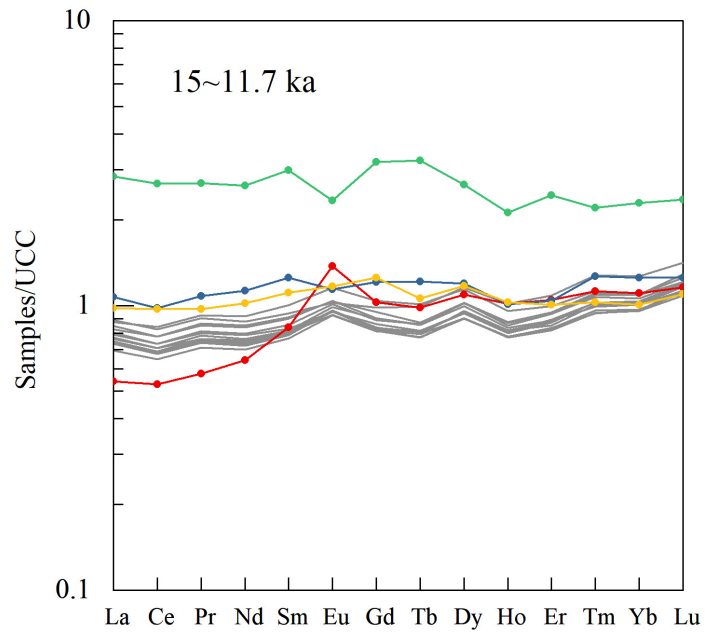

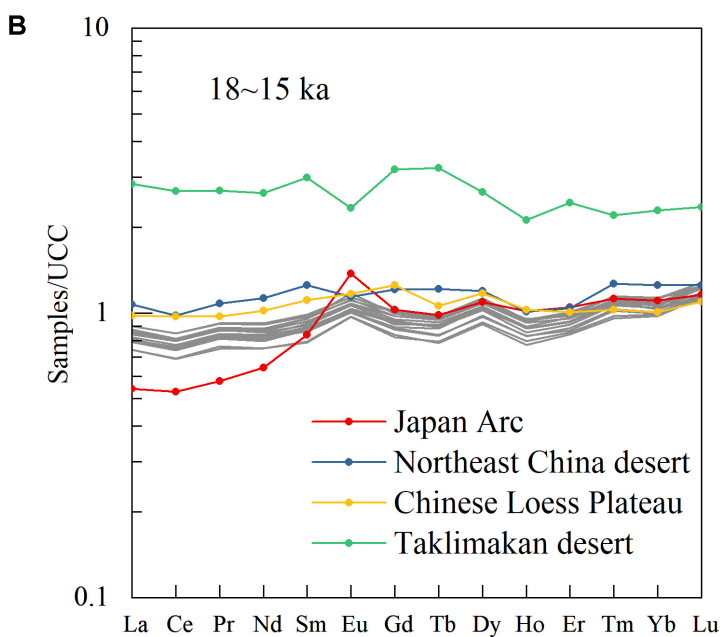

D

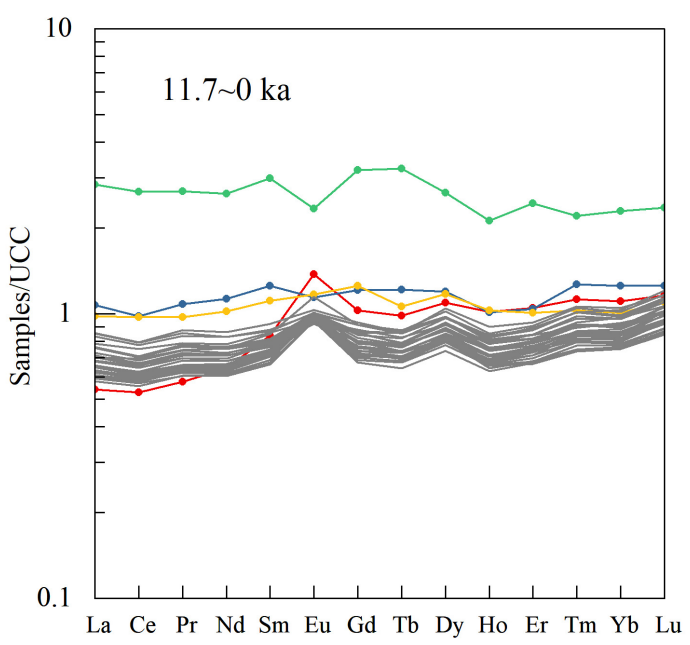

FIGURE 5 | Comparisons of UCC-normalized REE patterns among sediments of core LV53-18-2, Japan Arc (Togashi et al., 2000), Northeast China desert (Xie et al., 2019), Chinese Loess Plateau (Jahn et al., 2001), and Taklimakan desert (Yang X. et al., 2007). The REE patterns are shown with different periods: the late last glaciation (30 18 ka, A), early last deglacial period (18 15, B), late last deglacial period (15 11.7 ka, C), and the Holocene (11.7 0 ka, D).

portion in our records increases gradually with time and can reach $42 \%$ after $8 \mathrm{ka}$. The ratio of the mixing of two end members ( $\mathrm{A}$ and $\mathrm{B}$ ) can be calculated based on the binary mixing theory and the equation is as follows:

$$
f=\frac{X_{B}\left(R_{B}^{X}-R_{M}^{X}\right)}{X_{A}\left(R_{M}^{X}-R_{A}^{X}\right)+X_{B}\left(R_{B}^{X}-R_{M}^{X}\right)}
$$

where $f$ is the percentage of end members $\mathbf{A}$ and $\mathbf{B}, X_{A}$ and $X_{B}$ are the mean concentrations of $X$ in the components, $R_{M}^{X}$ represents the measured isotope ratio of $X$ in components $\mathbf{A}$ and $\mathbf{B}$, and $R_{A}^{X}$ and $R_{B}^{X}$ are isotopic ratios of $X$.

\section{Paleoenvironmental Implications From Provenance Variations}

To discuss provenance changes and controlling factors during the last $30 \mathrm{ka}$, we compared our records with the boreal insolation (Berger and Loutre, 1991), East Asian Summer Monsoon (EASM)
(Cheng et al., 2016), sea level reconstruction (Liu et al., 2004), and dust records from MD01-2407 (Nagashima et al., 2007a; Figure 10A-J). Although REE parameters and Sr-Nd isotope records suggest that sediments in core LV53-18-2 are formed owing to binary mixing including volcanic material and northern China (Figures 8, 9), we cannot determine the contribution from the Sikhote-Alin orogenic belt because of its complicated components and a direct comparison with our results is difficult.

\section{Wind and Sea Ice Control Effects on Sedimentation During the Late Last Glaciation}

The low boreal insolation enlarged the Northern Hemisphere ice sheet (Figure 10A), resulting in the strengthened Siberia High and East Asian Winter Monsoon (EAWM) during the late last glaciation (Sun et al., 2011). Meanwhile, the WJ accelerated and expanded over northern China (Nagashima et al., 2011). Previous dust records in southern core MD01-2407 and eastern core KT94-15-5 (Figure 1) have revealed the following: (1) that 

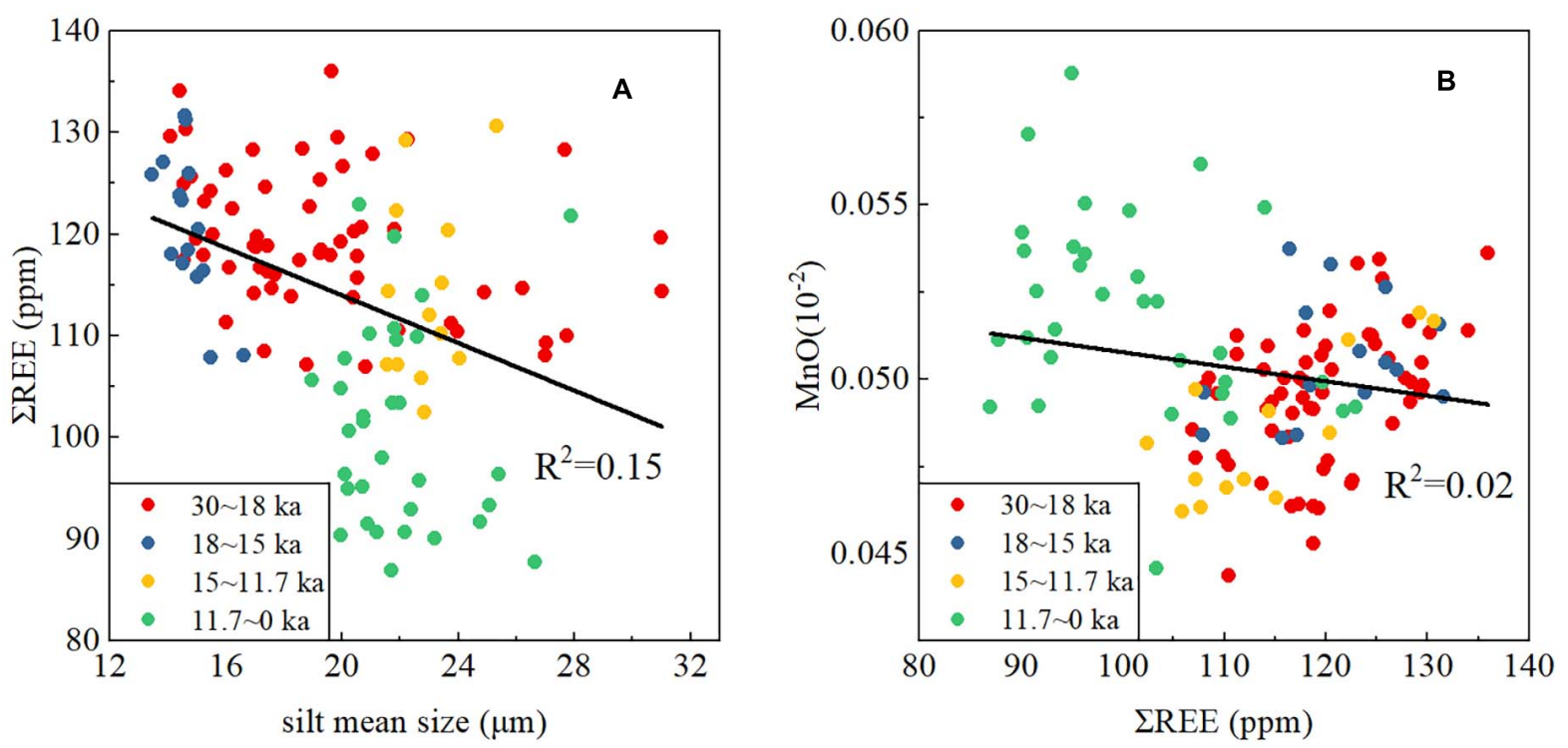

FIGURE 6 | Plots of correlations among $\Sigma$ REE, silt mean size (A), and MnO concentration (B) in core LV53-18-2.
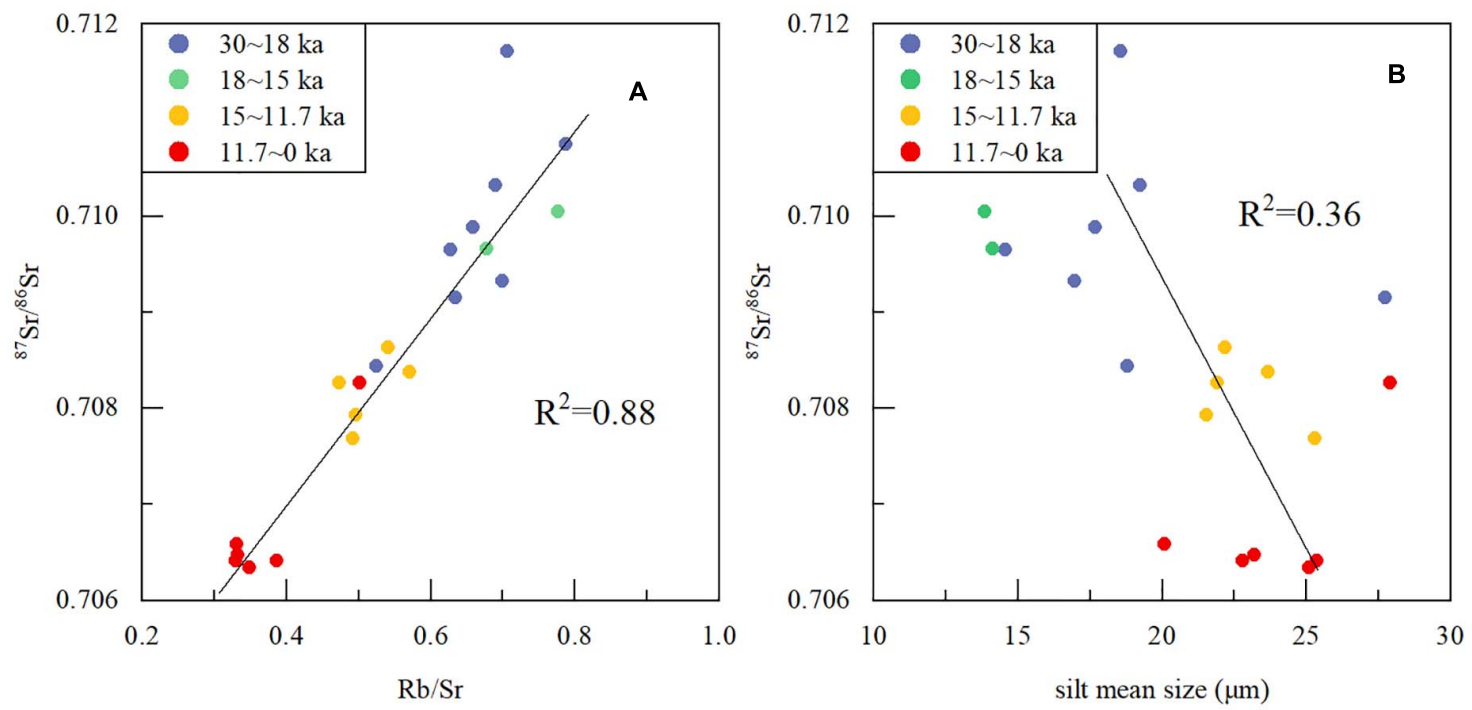

FIGURE 7 | Plots of correlations among ${ }^{87} \mathrm{Sr} /{ }^{86} \mathrm{Sr}, \mathrm{Rb} / \mathrm{Sr}$ (A), and silt mean size (B) in core LV53-18-2.

the strengthened EAWM would bring more dust from northern China to the eastern and southern JS and vice versa. (2) The WJ jumped northward and southward in response to the insolation change on the orbital scale. The WJ main axis was located south of the Tibet Plateau but its coverage expanded over northern China, facilitating the dust transportation of the EAWM during the glacial period. During the interglacial period, more dust from the Taklimakan Desert-China Loess Plateau could have been carried to southern JS because the WJ was narrowed and jumped to the north of the Tibet Plateau (Nagashima et al., 2007a; Nagashima et al., 2011). Some studies suggest that the WJ can influence the variability of the EAM on different timescales (Nagashima et al., 2013; Chowdary et al., 2019). Nevertheless, it is difficult to differentiate the respective influences of the WJ and the EAWM on aeolian dust deposition in the JS. In this study, these two types of dust transportation were considered as a single contribution because they both contributed to the delivery of aeolian dust to the JS during the last glacial period.

In contrast, low stand sea level (Figure 10C), another prominent phenomenon that is linked to the growth of ice sheets, enclosed the JS from open waters due to its shallow straits (Oba and Irino, 2012). Extremely light planktic foraminiferal $\delta^{18} \mathrm{O}$ and dominating terrigenous material from mainland China in the southwest JS during the late last 

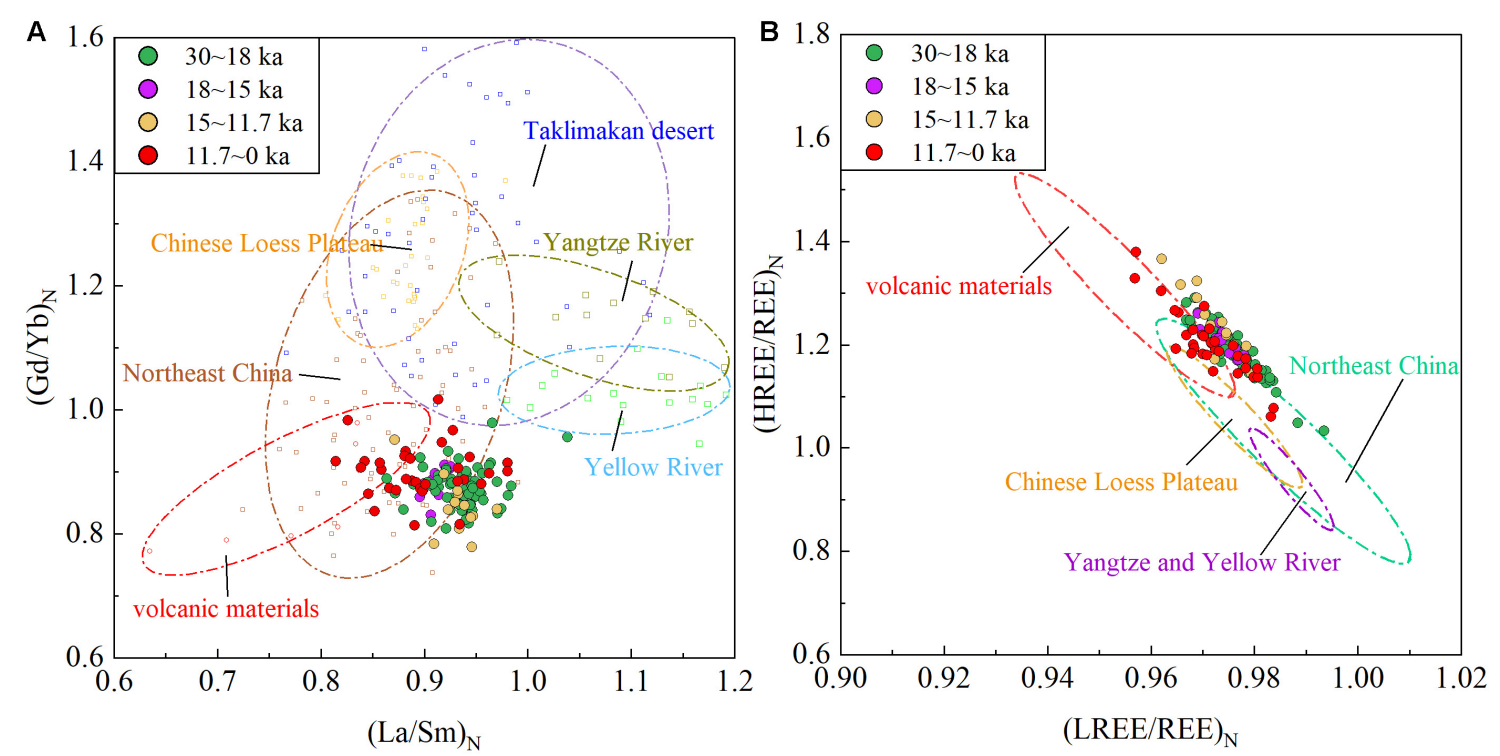

FIGURE 8 | Discrimination plots of $(\mathrm{Gd} / \mathrm{Yb})_{N}$ V.s. $(\mathrm{La} / \mathrm{Sm})_{N}(\mathbf{A})$ and $(\mathrm{LREE} / \mathrm{REE})_{N}$ V.s. (HREE/REE) $)_{N}$ (B) for the sediments of this study. Values of modern riverine sediments of Yangtze and Yellow Rivers (Yang et al., 2002), Japan Arc (Togashi et al., 2000), Northeast China desert (Xie et al., 2019), Chinese Loess Plateau (Jahn et al., 2001), and Taklimakan desert (Yang X. et al., 2007) are also shown for comparison.
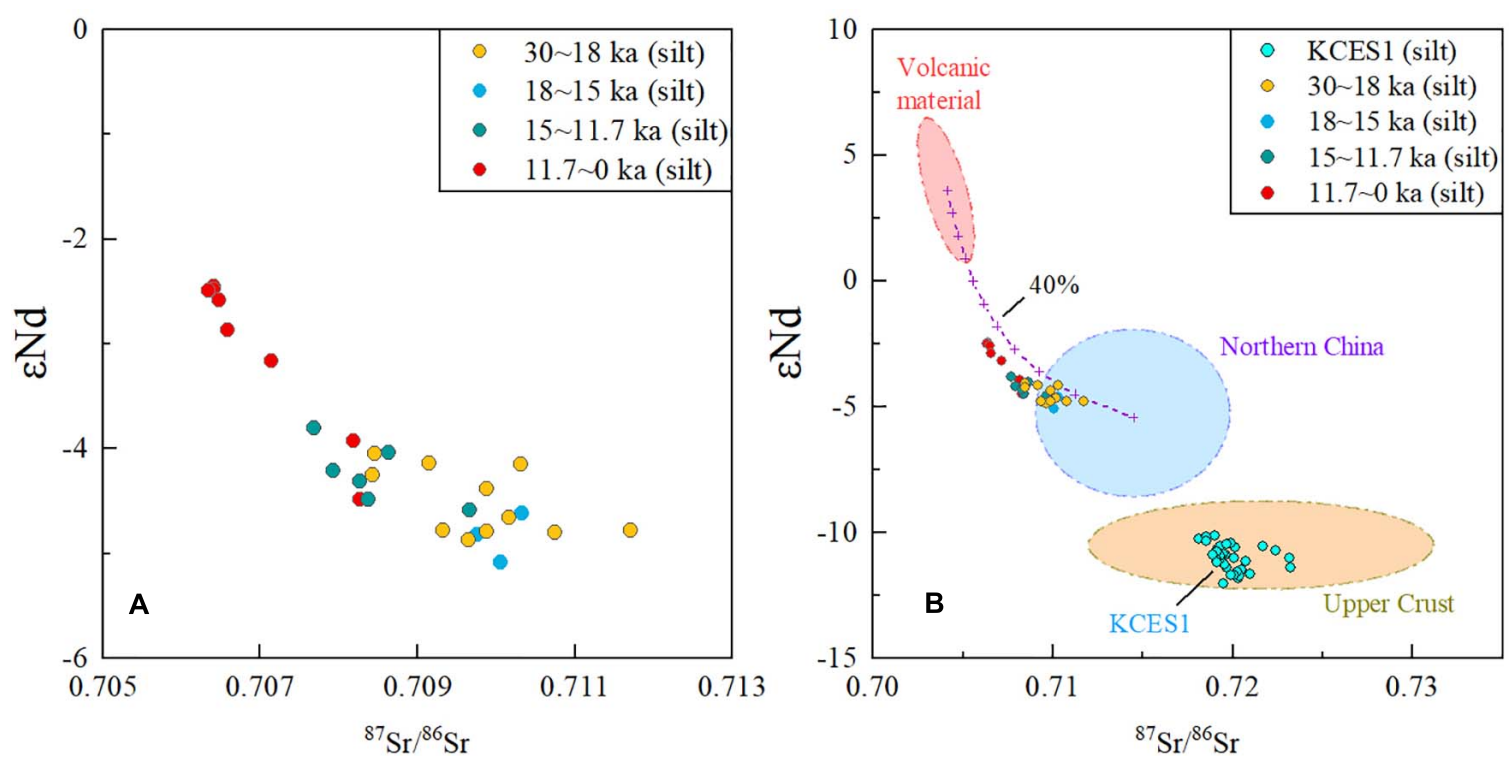

FIGURE 9 | Discrimination plots of $\varepsilon$ Nd v.s. ${ }^{87} \mathrm{Sr} /{ }^{86} \mathrm{Sr}$ in core LV53-18-2 sediments (A), in comparison with potential sources (B). The curve represents the proportion of the Japan Arc (Morris and Kagami, 1989) end-member $\left(\varepsilon N d=3.59,{ }^{87} \mathrm{Sr} /{ }^{86} \mathrm{Sr}=0.704142\right)$ mixing with the Mongolian Gobi (Zhao et al., 2015)-Northeast China desert (Chen et al., 2007) end-member $\left(\varepsilon N d=-5.4,{ }^{87} \mathrm{Sr} /{ }^{86} \mathrm{Sr}=0.7145\right)$.

glaciation especially the LGM indicated that the restrained TWC (Gorbarenko and Southon, 2000; Domitsu and Oda, 2006) and more freshwater input by Chinese rivers led to upper column stratification. Previous research reported that sea ice expanded significantly southward, because of freshwater input and the strengthened EAWM, and reached $40^{\circ} \mathrm{N}$ during the LGM (Ikehara, 2003). Furthermore, another study observed that the peaks of Ice-Rafted Debris (IRD) could be linked to the intensity of the EAWM on millennial-centurial timescales during MIS 3 and 4 (Ikehara and Fujine, 2012).

Our records reveal that terrigenous debris was mainly derived from northern China during the LGM, which is supported by previous research that the strengthened EAWM and expansion of the WJ brought more dust from Gobi-Northeast China to the JS during the glacial period (Nagashima et al., 2007a). Notably, $\mathrm{REE}$ and $\mathrm{Sr}-\mathrm{Nd}$ isotope results changed significantly when sea ice 


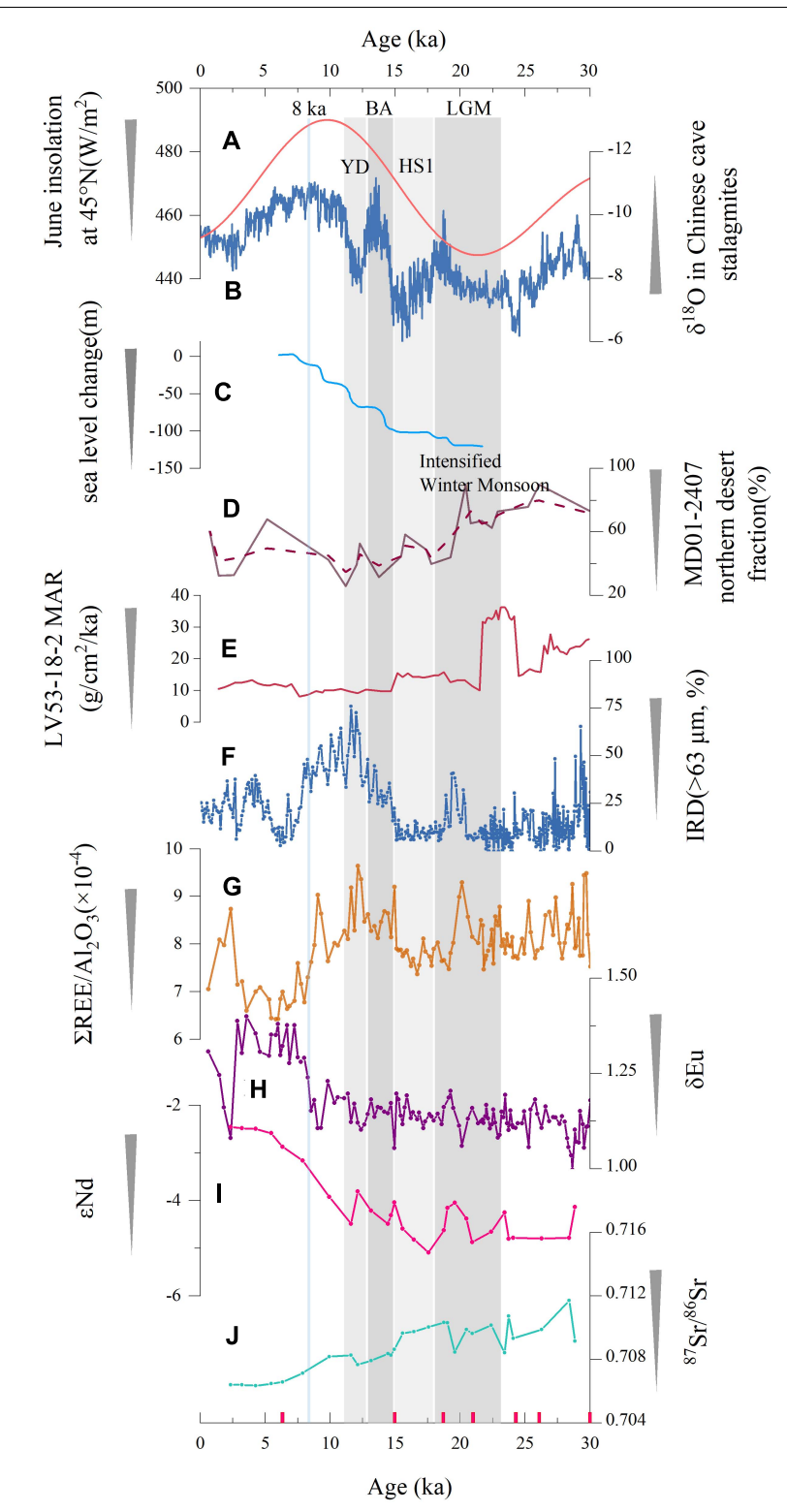

FIGURE 10 | Comparison of global and regional records during the last glacial period. June insolation at $45^{\circ} \mathrm{N}$ (A) (Berger and Loutre, 1991), Chinese speleothem $\delta^{18} \mathrm{O}$ (B) (Cheng et al., 2016), sea level curve of China Seas (C) (Liu et al., 2004), dust fraction of Gobi-Northeast China desert in core MD01-2407 (D) (Nagashima et al., 2007a), REEs mass accumulation rates (E), sea ice indicator (F) (Dou et al., 2020), $\mathrm{REEs} / \mathrm{Al}_{2} \mathrm{O}_{3}$ ratio (G), Eu anomaly curve $\mathbf{( H )}$, radiogenic isotopes record in core LV53-18-2 (I,J). LGM, the Last Glaciation Maximum; $\mathrm{H} 1$, the Heinrich stadial 1 cold event; B/A, the Bølling-Allerød warming event; YD, the Younger Dryas cold event. Red rectangles denote age control points.

activity was intensified on the millennium scale during the last glaciation indicated by IRD peaks (Figures 10F-J). Sea ice can erode bedrock along with the coastal orogenic belt and transport quantities of weakly weathered detritus including heavy minerals and volcanic ash for long distances (Heinrich, 1988), resulting in the enrichment of $\Sigma$ REE and/or radiogenic $\varepsilon N d$ when sea ice melts (McLennan, 1989). Thus, our records suggest that northern China and the coastal orogenic belt were the main provenances of LV53-18-2 during the late last glaciation. Detritus from the former source was delivered by atmospheric circulation (the EAWM and WJ) and later source-to-sink processes were mainly achieved by sea ice transportation on a millennium scale.

\section{Persistent Sea Ice Coverage During the Heinrich Stadial 1}

The abrupt increase in planktic foraminifera $\delta^{18} \mathrm{O}$ values indicated the inflow of relatively saline and cold water from the East China coast into the JS through the Tsushima Strait during HS1 (Domitsu and Oda, 2006). Redox-sensitive elements, radiolarian proxies, and reappearance of benthic foraminifera suggest that deep-water ventilation was enhanced in the eastern and centeral JS (Domitsu and Oda, 2006; Zou et al., 2012; Dong et al., 2020; Dong et al., 2021). In addition to the provenance change documented in core KCES1 (Zou et al., 2021), this evidence demonstrated that an intrusion of paleo-TWC into the JS due to the reopening of the Tsushima Strait during HS1.

In contrast to ventilation improvement and provenance change in the southwest JS, our records showed no evident element variations and marked low IRD contents compared to the LGM. The weakened sea ice activity yields two distinct assumptions, namely, no sea ice coverage or persistent/perennial sea ice coverage. We infer the following. (1) The latter assumption supported by the mean grain size of the Gulang Loess (Sun et al., 2011) and Chinese speleothems $\delta^{18} \mathrm{O}$ records (Cheng et al., 2016), indicates stronger EAWM and weakened EASM, coinciding with iceberg melting events in the North Atlantic. (2) $\mathrm{U}^{K^{\prime}}{ }_{37}$-temperatures at southern ODP797, MD01-2407 and eastern MD01-2408 both display a cold peak of surface water during HS1 (Fujine et al., 2009; Liu et al., 2014). (3) The frontier of sea ice melting is still located south of $42^{\circ} \mathrm{N}$ (Ikehara, 2003). This evidence supports the hypothesis that cold conditions prevail during HS1 and facilitate sea ice formation and preservation.

Our records emphasize the different responses to sea level and monsoon changes in the interior JS during HS1 (Shi et al., 2019; Dong et al., 2021). Sea level rise induced the enhancement of ventilation, hydrologic sorting, and change of provenance in the southern JS during HS1, but it had a smaller impact on the paleoenvironmental evolution of western JS compared to that of EAM.

\section{Multi-Millennial Sea Ice Variations During the Last Deglaciation and Early Holocene}

The raised boreal summer insolation enhanced the EASM, transporting more moisture and heat to arid regions, thereby ameliorating the climate in East Asia. In contrast, the decay of the northern ice sheet diminished the Siberia High and accelerated the rise of the global sea level (Denton et al., 2010). The dust flux from KT94-15-5 and the northern desert fraction of MD01-2407 decreased remarkably in response to the weakened EAWM and narrowed WJ (Nagashima et al., 2007a). Combined with the entry of the Oyashio Current via the Tsugaru Strait after $15.6 \mathrm{ka}$, ventilation in the southern and eastern JS is ameliorated continuously (Itaki et al., 2004; 
Domitsu and Oda, 2006). Meanwhile, the abrupt enhancement of the EASM facilitated the input of nutrient-rich freshwater from East Asian rivers and increased primary productivity (Zou et al., 2012).

The chemical compositions in our core during this interval shift to volcanic end members and are different from the aeolian dust derived from northern China. The decreased dust input from northern China can explain the MAR in our core, evidenced by similar trends in the dust records of KT94-15-5 and MD012407. In addition, our data also recorded violent melting and enhanced hydrodynamics since the onset of Bølling-Allerød (BA) warming event (Figure 3B) and weakened melting after the early Holocene, which is in concert with boreal summer insolation and EASM changes. Insolation-driven melting is also supported by the IRD records in the upstream core LV32-33 (Gorbarenko et al., 2014). Similar to sea ice activity on millennials during the late last glaciation period, an increased proportion of IRD deposition could significantly influence the composition of sediments in this core.

The reason for the difference in the degrees of ice melting during the HS1 and YD events must be clarified. Taking high sea level and boreal insolation into consideration, we argue that more favorable conditions for summer sea ice melting (e.g., stronger EASM and intrusion of warmer waters induced by high sea level) prevail in YD compared to the corresponding conditions in HS1.

\section{Development of the Liman Cold Current Since the Middle Holocene}

Boreal insolation decreased after the early Holocene Optimum and environmental deterioration would be conducive to dust transportation (Chen et al., 2008). As stated earlier, almost all elemental proxies show prominent variations after 8 ka. Generally, intermediate and felsic volcanic materials are enriched with REE-depleted quartz and plagioclase, and Eu$\mathrm{Ca}$ isomorphous substitution occurs commonly in Ca-enriched plagioclase (Franzese and Hemming, 2013). Higher mafic fraction, low REE concentrations, and remarkably positive Eu anomaly together indicate the input of continuous volcanic materials through the last $8 \mathrm{ka}$. However, it is unreasonable to attribute volcanic input to sea ice activity because of the trends are not similar, and the development of coastal current is another rational explanation.

In the modern era, the LCC originates from melting ice around the Tatar Strait, which is supplied mainly by fresh water delivered from the Amur River (Martin and Kawase, 1998). The connection between JS and open waters is limited and the LCC can barely develop in the condition of low sea level until the sea level rises to $-15 \mathrm{~m}$ (Liu et al., 2004). When the sea level rises to the height corresponding to the opening of the Tatar strait at 9-8 ka, the fresh water input by the Amur River and subsequent erosion and transportation by the current along the coast are characterized by a Cretaceous island arc system and could increase the proportion of volcanic materials in sediments (Jahn et al., 2015).

Previous studies have demonstrated that the TWC continuously entered the JS at around 9 to $7 \mathrm{ka}$ (Itaki et al., 2004; Dong et al., 2020; Zou et al., 2021), which is almost synchronous with the development of the LCC. Therefore, we infer that $8 \mathrm{ka}$ represents the critical time indicator of the formation of the modern surface circulation system in the JS.

\section{CONCLUSION}

Based on the analysis of minor elements (REEs, Th, Zr, and Sc) and $\mathrm{Sr}-\mathrm{Nd}$ isotope in the fine detrital component $(<63 \mu \mathrm{m})$ of gravity core LV53-18-2, this study has discussed the provenance and controlling factors in the western JS during the last 30 ka. We conclude that: (1) the main terrigenous provenance of this core is the northern China and Sikhote-Alin orogenic belt in the Far East. The intensity of atmospheric circulation, sea ice activity, and ocean currents are the primary factors that influence sediment deposition. (2) During the late glacial period/LGM, intensified atmospheric circulation (the East Asian Winter Monsoon and Westerly Jet) transported more dust from northern China, while sea ice activity on the millennium scale was facilitated by coastal supply. Climatic transformation in the deglacial period significantly diminished the ability of wind transportation and increased the amount of IRD deposits due to high boreal insolation, which remarkably affected sediment composition remarkably. (3) We infer that the development of the Liman Cold Current, occurring at about $8 \mathrm{ka}$, was induced by the rise in sea level and subsequent opening of the Tatar Strait.

\section{DATA AVAILABILITY STATEMENT}

The raw data supporting the conclusions of this article will be made available by the authors, without undue reservation.

\section{AUTHOR CONTRIBUTIONS}

XS and JZ conceived the study. XS, SG, and JZ collected the samples. RD, AZ, LH, JG, YZ, and JC completed the experiments. $\mathrm{RD}$ analyzed the data, wrote the manuscript with contributions from all co-authors. All authors contributed to the article and approved the submitted version.

\section{FUNDING}

Financial support was provided by the National Program on Global Change and Air-Sea Interaction (GASI-GEOGE-04), the National Natural Science Foundation of China (Grant Nos.: U1606401, 41206059, 41876065, and 41420104005), the Basic Scientific Fund for National Public Research Institutes of China (No. 2016Q09), and Taishan Scholars Program of Shandong (TSQN20182117).

\section{ACKNOWLEDGMENTS}

We thank the ship crew and other participants for their assistance during cruise LV53. 


\section{REFERENCES}

Berger, A., and Loutre, M. F. (1991). Insolation values for the climate of the last 10 million years. Q. Sci. Rev. 10, 297-317. doi: 10.1016/0277-3791(91)90 033-Q

Cao, P., Shi, X., Li, W., Liu, S., Yao, Z., Hu, L., et al. (2015). Sedimentary responses to the Indian Summer Monsoon variations recorded in the southeastern Andaman Sea slope since 26 ka. J. Asian Earth Sci. 114, 512-525. doi: 10.1016/j.jseaes.2015. 06.028

Chen, F., Yu, Z., Yang, M., Ito, E., Wang, S., Madsen, D. B., et al. (2008). Holocene moisture evolution in arid central Asia and its out-of-phase relationship with Asian monsoon history. Quat. Sci. Rev. 27, 351-364. doi: 10.1016/j.quascirev. 2007.10.017

Chen, J., Li, G., Yang, J., Rao, W., Lu, H., Balsam, W., et al. (2007). Nd and Sr isotopic characteristics of Chinese deserts: implications for the provenances of Asian dust. Geochim. Cosmochim. Acta 71, 3904-3914. doi: 10.1016/j.gca.2007. 04.033

Cheng, H., Edwards, R. L., Sinha, A., Spotl, C., Yi, L., Chen, S., et al. (2016). The Asian monsoon over the past 640,000 years and ice age terminations. Nature 534, 640-646. doi: 10.1038/nature18591

Chowdary, J. S., Hu, K., Srinivas, G., Kosaka, Y., Wang, L., and Rao, K. K. (2019). The Eurasian jet streams as conduits for East Asian monsoon variability. Curr. Clim. Chang. Rep. 5, 233-244. doi: 10.1007/s40641-019-00 $134-\mathrm{x}$

Chun, J.-H., Cheong, D., Ikehara, K., and Han, S.-J. (2007). Age of the SKPI and SKP-II tephras from the southern East Sea/Japan sea: implications for interstadial events recorded in sediment from marine isotope stages 3 and 4. Palaeogeogr. Palaeoclimatol. Palaeoecol. 247, 100-114. doi: 10.1016/j.palaeo. 2006.11.024

Denton, G. H., Anderson, R. F., Toggweiler, J. R., Edwards, R. L., Schaefer, J. M., and Putnam, A. E. (2010). The last glacial termination. Science 328, 1652-1656. doi: $10.1126 /$ science. 1184119

Domitsu, H., and Oda, M. (2006). Linkages between surface and deep circulations in the southern Japan Sea during the last 27,000 years: evidence from planktic foraminiferal assemblages and stable isotope records. Mar. Micropaleontol. 61, 155-170. doi: 10.1016/j.marmicro.2006

Dong, Z., Shi, X., Ge, C., Zou, J., Yao, Z., Gorbarenko, S., et al. (2017). Evolution of westerly jet during the last $60 \mathrm{ka}$ : evidence from core deposits in the central Japan (East) Sea. Chin. Sci. Bull. 62, 1172-1184. (In Chinese with English abstract), doi: 10.1360/n972016-00861

Dong, Z., Shi, X., Zou, J., Zou, X., Chen, M., Zhang, Q., et al. (2020). Drastic hydrographic changes inferred from radiolarian assemblages in the central Japan Sea since the last glacial maximum. Mar. Geol. 429:106295. doi: 10.1016/ j.margeo.2020.106295

Dong, Z., Shi, X., Zou, J., Zou, X., Dou, R., Wu, Y., et al. (2021). Paleoceanographic insights on meridional ventilation variations in the Japan sea since the last glacial maximum: a radiolarian assemblage perspective. Glob. Planet. Chang. 200:103456. doi: 10.1016/j.gloplacha.2021.103456

Dou, R., Zou, J., Shi, X., Zhu, A., Dong, Z., Shi, F., et al. (2020). Reconstructed changes in sea ice in the western Sea of Japan over the last 30,000 years. Quat. Sci. 40, 690-703. (In Chinese with English abstract), doi: 10.11928/j.issn.10017410.2020 .03 .08

Franzese, A. M., and Hemming, S. R. (2013). PALEOCEANOGRAPHY, PHYSICAL AND CHEMICAL PROXIES | Terrigenous Sediments, Encyclopedia of Quaternary Science. (Amsterdam; Elsevier), 941-953.

Fujine, K., Tada, R., and Yamamoto, M. (2009). Paleotemperature response to monsoon activity in the Japan Sea during the last $160 \mathrm{kyr}$. Palaeogeogr. Palaeoclimatol. Palaeoecol. 280, 350-360. doi: 10.1016/j.palaeo.2009. 06.022

Goldstein, S. L., O’Nions, R. K., and Hamilton, P. J. (1984). A Sm-Nd isotopic study of atmospheric dusts and particulates from major river systems. Earth Planet. Sci. Lett. 70, 221-236. doi: 10.1016/0012-821X(84)90 007-4

Gorbarenko, S. A., Nam, S.-I., Rybiakova, Y. V., Shi, X., Liu, Y., and Bosin, A. A. (2014). High resolution climate and environmental changes of the northern Japan (East) Sea for the last 40kyr inferred from sedimentary geochemical and pollen data. Palaeogeogr. Palaeoclimatol. Palaeoecol. 414, 260-272. doi: 10.1016/ j.palaeo.2014.09.001
Gorbarenko, S. A., and Southon, J. R. (2000). Detailed Japan Sea paleoceanography during the last $25 \mathrm{kyr}$ : constraints from AMS dating and $\delta 18 \mathrm{O}$ of planktonic foraminifera. Palaeogeogr. Palaeoclimatol. Palaeoecol. 156, 177-193. doi: 10. 1016/S0031-0182(99)00137-6

Grebennikov, A. V., Khanchuk, A. I., Gonevchuk, V. G., and Kovalenko, S. V. (2016). Cretaceous and paleogene granitoid suites of the Sikhote-Alin area (Far East Russia): geochemistry and tectonic implications. Lithos 261, 250-261. doi: 10.1016/j.lithos.2015. 12.020

Grousset, F. E., Biscaye, P. E., Zindler, A., Prospero, J., and Chester, R. (1988). Neodymium isotopes as tracers in marine sediments and aerosols: North Atlantic. Earth Planet. Sci. Lett. 87, 367-378. doi: 10.1016/0012-821X(88) 90001-5

Heinrich, H. (1988). Origin and consequences of cyclic ice rafting in the Northeast Atlantic ocean during the past 130,000 years. Quat. Res. 29, 142-152. doi: 10.1016/0033-5894(88)90057-9

Ikehara, K. (2003). Late quaternary seasonal sea-ice history of the Northeastern Japan sea. J. Oceanogr. 59, 585-593. doi: 10.1023/B:JOCE.0000009588.499 $44.3 \mathrm{~d}$

Ikehara, K., and Fujine, K. (2012). Fluctuations in the late quaternary East Asian winter monsoon recorded in sediment records of surface water cooling in the northern Japan Sea. J. Quat. Sci. 27, 866-872. doi: 10.1002/jqs. 2573

Irino, T., and Tada, R. (2000). Quantification of aeolian dust (Kosa) contribution to the Japan Sea sediments and its variation during the last $200 \mathrm{ky}$. Geochem. J. 34, 59-93. doi: 10.2343/geochemj.34.59

Itaki, T., Ikehara, K., Motoyama, I., and Hasegawa, S. (2004). Abrupt ventilation changes in the Japan Sea over the last $30 \mathrm{ky}$ : evidence from deep-dwelling radiolarians. Palaeogeogr. Palaeoclimatol. Palaeoecol. 208, 263-278. doi: 10. 1016/j.palaeo.2004.03.010

Jacobsen, S. B., and Wasserburg, G. J. (1980). Sm-Nd isotopic evolution of chondrites. Earth Planet. Sci. Lett. 50, 139-155. doi: 10.1016/0012-821X(80) 90125-9

Jahn, B.-m., Gallet, S., and Han, J. (2001). Geochemistry of the Xining, Xifeng and Jixian sections, Loess Plateau of China: eolian dust provenance and paleosol evolution during the last $140 \mathrm{ka}$. Chem. Geol. 178, 71-94. doi: 10.1016/S00092541(00)00430-7

Jahn, B.-m., Valui, G., Kruk, N., Gonevchuk, V., Usuki, M., and Wu, J. T. J. (2015). Emplacement ages, geochemical and $\mathrm{Sr}-\mathrm{Nd}-\mathrm{Hf}$ isotopic characterization of Mesozoic to early Cenozoic granitoids of the SikhoteAlin Orogenic Belt, Russian Far East: crustal growth and regional tectonic evolution. J. Asian Earth Sci. 111, 872-918. doi: 10.1016/j.jseaes.2015. 08.012

Kim, K., Chang, K. I., Kang, D. J., Kim, Y. H., and Lee, J. H. (2008). Review of recent findings on the water masses and circulation in the East Sea (Sea of Japan). J. Oceanogr. 64, 721-735. doi: 10.1007/s10872-008-0 061-X

Liu, J. P., Milliman, J. D., Gao, S., and Cheng, P. (2004). Holocene development of the Yellow River's subaqueous delta, North Yellow Sea. Mar. Geol. 209, 45-67. doi: 10.1016/j.margeo.2004.06.009

Liu, Y., Chen, J., Chen, X., Zou, J., and Yao, Z. (2014). Variations of alkenone temperature in the Sea of Japan during the last $170 \mathrm{ka}$ and its paleoceanographic implications. Chin. Sci. Bull. 59, 4498-4509. doi: 10.1007/s11434-014-0367-6

Mahoney, J. B. (2005). Nd and Sr isotopic signatures of fine-grained clastic sediments: a case study of western Pacific marginal basins. Sediment. Geol. 182, 183-199. doi: 10.1016/j.sedgeo.2005.07.009

Martin, S., and Kawase, M. I. (1998). The southern flux of sea ice in the Tatarskiy Strait, Japan Sea and the generation of the Liman current. J. Mar. Res. 56, 141-155. doi: 10.1357/00222409832183 6145

McLennan, S. M. (1989). Rare earth elements in sedimentary rocks: influence of provenance and sedimentary processes. Rev. Minerol. Geochem. 21, 170-199. doi: 10.1007/BF00209706

Mclennan, S. M., Hemming, S. R., Mcdaniel, D. K., and Hanson, G. N. (1993). Geochemical approaches to sedimentation, provenance, and tectonics. Geol. Soc. Am. 284, 21-40. doi: 10.1130/SPE284-p21

McLennan, S. M., Taylor, S. R., McCulloch, M. T., and Maynard, J. B. (1990). Geochemical and Nd Sr isotopic composition of deep-sea turbidites: crustal 
evolution and plate tectonic associations. Geochim. Cosmochim. Acta 54, 2015 2050. doi: 10.1016/0016-7037(90)90269-Q

Meng, X., Liu, Y., Shi, X., and Du, D. (2008). Nd and Sr isotopic compositions of sediments from the Yellow and Yangtze Rivers: implications for partitioning tectonic terranes and crust weathering of the Central and Southeast China. Front. Earth Sci. China 2:418-426. doi: 10.1007/s11707-0080054-5

Milliman, J. D., and Meade, R. H. (1983). World-Wide delivery of river sediment to the oceans. J. Geol. 91, 1-21. doi: 10.1086/628741

Morris, P. A., and Kagami, H. (1989). Nd and Sr isotope systematics of miocene to holocene volcanic rocks from Southwest Japan: volcanism since the opening of the Japan Sea. Earth Planet. Sci. Lett. 92, 335-346. doi: 10.1016/0012-821X(89) 90058-7

Nagashima, K., Tada, R., Matsui, H., Irino, T., Tani, A., and Toyoda, S. (2007a). Orbital-and millenial-scale variations in Asian dust transport path to the Japan Sea. Palaeogeogr. Palaeoclimatol. Palaeoecol. 247, 144-161. doi: 10.1016/j. palaeo.2006.11.027

Nagashima, K., Tada, R., Tani, A., Sun, Y., Isozaki, Y., Toyoda, S., et al. (2011). Millennial-scale oscillations of the westerly jet path during the last glacial period. J. Asian Earth Sci. 40, 1214-1220. doi: 10.1016/j.jseaes.2010. 08.010

Nagashima, K., Tada, R., Tani, A., Toyoda, S., Sun, Y., and Isozaki, Y. (2007b). Contribution of aeolian dust in Japan Sea sediments estimated from ESR signal intensity and crystallinity of quartz. Geochem. Geophys. Geosyst. 8, 144-161. doi: $10.1029 / 2006 \mathrm{gc001364}$

Nagashima, K., Tada, R., and Toyoda, S. (2013). Westerly jet-East Asian summer monsoon connection during the Holocene. Geochem. Geophys. Geosyst. 14, 5041-5053. doi: 10.1002/2013gc004931

Nihashi, S., Ohshima, K. I., and Saitoh, S.-I. (2017). Sea-ice production in the northern Japan Sea. Deep Sea Res. I Oceanogr. Res. Papers 127, 65-76. doi: 10.1016/j.dsr.2017.08.003

Nürnberg, D., and Tiedemann, R. (2004). Environmental change in the Sea of Okhotsk during the last 1.1 million years. Paleoceanography 19, n/a-n/a. doi: $10.1029 / 2004 \mathrm{pa} 001023$

Oba, T., and Irino, T. (2012). Sea level at the last glacial maximum, constrained by oxygen isotopic curves of planktonic foraminifera in the Japan Sea. J. Quat. Sci. 27, 941-947. doi: 10.1002/jqs.2585

Park, K. A., Kim, K., Cornillon, P. C., and Chung, J. Y. (2006). Relationship between satellite-observed cold water along the Primorye coast and sea ice in the East Sea (the Sea of Japan). Geophys. Res. Lett. 33, 229-237. doi: 10.1029/2005GL02 5611

Park, K. A., Ullman, D. S., Kim, K., Chung, J. Y., and Kim, K. R. (2007). Spatial and temporal variability of satellite-observed Subpolar Front in the East/Japan Sea. Deep Sea Res I Oceanogr. Res. Papers 54, 453-470. doi: 10.1016/j.dsr.2006.12.010

Porter, S. C., and An, Z. (1995). Correlation between climate events in the North Atlantic and China during the last glaciation. Nature 375, 305-308. doi: 10. 1038/375305a0

Shen, X., Wan, S., France-Lanord, C., Clift, P. D., Tada, R., Révillon, S., et al. (2017). History of Asian eolian input to the Sea of Japan since 15 Ma: links to Tibetan uplift or global cooling? Earth Planet. Sci. Lett. 474, 296-308. doi: 10.1016/j.epsl.2017.06.053

Shi, X., Zou, J., Yao, Z., and Dou, R. (2019). Sedimentation and environment evolution of the Sea of Japan since the last glaciation and its driving forces. Mar. Geol. Quat. Geol. 39, 1-11. (In Chinese with English abstract), doi: 10.16562/j. cnki.0256-1492.2019.050801

Sun, Y., Clemens, S. C., Morrill, C., Lin, X., Wang, X., and An, Z. (2011). Influence of Atlantic meridional overturning circulation on the East Asian winter monsoon. Nat. Geosci. 5, 46-49. doi: 10.1038/ngeo1326

Tada, R. (1994). Paleoceanographic evolution of the Japan Sea. Palaeogeogr. Palaeoclimatol. Palaeoecol. 108, 487-508. doi: 10.1016/0031-0182(94)90248-8

Tada, R., Irino, T., Ikehara, K., Karasuda, A., Sugisaki, S., Xuan, C., et al. (2018). High-resolution and high-precision correlation of dark and light layers in the quaternary hemipelagic sediments of the Japan Sea recovered during IODP Expedition 346. Prog. Earth Planet. Sci. 5:19. doi: 10.1186/s40645-0180167-8

Taylor, S. R., and McLennan, S. M. (1995). The geochemical evolution of the continental crust. Rev. Geophys. 33, 241-265. doi: 10.1029/95rg00262
Togashi, S., Imai, N., Okuyama-Kusunose, Y., Tanaka, T., Okai, T., Koma, T., et al. (2000). Young upper crustal chemical composition of the orogenic Japan Arc. Geochem. Geophys. Geosyst. 1:1049. doi: 10.1029/2000GC00 0083

Um, I. K., Choi, M. S., Bahk, J. J., and Chun, J. H. (2017). Provenance of late quaternary sediments on the southwestern slope of the Ulleung Basin, East/Japan Sea. Quat. Int. 459, 153-164. doi: 10.1016/j.quaint.2017. 04.013

Um, I. K., Man, S. C., Bahk, J. J., and Yun, H. S. (2013). Discrimination of sediment provenance using rare earth elements in the Ulleung Basin, East/Japan Sea. Mar. Geol. 346, 208-219. doi: 10.1016/j.margeo.2013.09.007

Vital, H., and Stattegger, K. (2000). Major and trace elements of stream sediments from the lowermost Amazon River. Chem. Geol. 168, 151-168. doi: 10.1016/ S0009-2541(00)00191-1

Walter, H. J., Hegner, E., Diekmann, B., Kuhn, G., and Rutgers van der loeff, M. M. (2000). Provenance and transport of terrigenous sediment in the south Atlantic Ocean and their relations to glacial and interglacial cycles: $\mathrm{Nd}$ and Sr isotopic evidence. Geochim. Cosmochim. Acta 64, 3813-3827. doi: 10.1016/ S0016-7037(00)00476-2

Wang, P. (1999). Response of Western Pacific marginal seas to glacial cycles: paleoceanographic and sedimentological features. Mar. Geol. 156, 5-39. doi: 10.1016/S0025-3227(98)00172-8

Wang, Y., Cheng, H., Edwards, R. L., He, Y., Kong, X., An, Z., et al. (2005). The Holocene Asian monsoon: links to solar changes and North Atlantic climate. Science 308, 854-857. doi: 10.1126/science.1106296

Wu, Y., Shi, X., Gong, X., Jian, Z., Zou, J., Liu, Y., et al. (2020). Evolution of the upper ocean stratification in the Japan Sea since the last glacial. Geophys. Res. Lett. 47:e2020GL088255. doi: 10.1029/2020gl088255

Xie, Y., Kang, C., Chi, Y., Du, H., Wang, J., and Sun, L. (2019). The loess deposits in Northeast China: the linkage of loess accumulation and geomorphic-climatic features at the easternmost edge of the Eurasian loess belt. J. Asian Earth Sci. 181:103914. doi: 10.1016/j.jseaes.2019.103914

Xu, Z., Lim, D., Choi, J., Li, T., Wan, S., and Rho, K. (2014). Sediment provenance and paleoenvironmental change in the Ulleung Basin of the East (Japan) Sea during the last 21 kyr. J. Asian Earth Sci. 93, 146-157. doi: 10.1016/j.jseaes.2014. 07.026

Yang, L., Long, H., Yi, L., Li, P., Wang, Y., Gao, L., et al. (2015). Luminescence dating of marine sediments from the Sea of Japan using quartz OSL and polymineral pIRIR signals of fine grains. Quat. Geochronol. 30, 257-263. doi: 10.1016/j.quageo.2015.05.003

Yang, S., Jiang, S., Ling, H., Xia, X., Sun, M., and Wang, D. (2007). Sr-Nd isotopic compositions of the Changjiang sediments: implications for tracing sediment sources. Sci. China D Earth Sci. 50, 1556-1565. doi: 10.1007/s11430-0070052-6

Yang, S., Jung, H., Choi, M., and Li, C. (2002). The rare earth element compositions of the Changjiang (Yangtze) and Huanghe (Yellow) river sediments. Earth Planet. Sci. Lett. 201, 407-419. doi: 10.1016/S0012-821X(02)00715-X

Yang, X., Zhu, B., and White, P. D. (2007). Provenance of aeolian sediment in the Taklamakan Desert of western China, inferred from REE and major-elemental data. Quat. Int. 175, 71-85. doi: 10.1016/j.quaint.2007.03.005

Zhang, W., De Vleeschouwer, D., Shen, J., Zhang, Z., and Zeng, L. (2018). Orbital time scale records of Asian eolian dust from the Sea of Japan since the early Pliocene. Quat. Sci. Rev. 187, 157-167. doi: 10.1016/j.quascirev.2018.03.004

Zhang, Y., Zhu, K., Huang, C., Kong, D., He, Y., Wang, H., et al. (2019). Asian winter monsoon imprint on holocene SST changes at the Northern coast of the South China Sea. Geophys. Res. Lett. 46, 13363-13370. doi: 10.1029/ $2019 \mathrm{gl085617}$

Zhao, D., Wan, S., Song, Z., Gong, X., Zhai, L., Shi, X., et al. (2019). Asynchronous variation in the quaternary East Asian winter monsoon associated with the tropical Pacific ENSO-like system. Geophys. Res. Lett. 46, 6955-6963. doi: 10. 1029/2019gl083033

Zhao, W., Sun, Y., Balsam, W., Zeng, L., Lu, H., Otgonbayar, K., et al. (2015). Clay-sized Hf-Nd-Sr isotopic composition of Mongolian dust as a fingerprint for regional to hemispherical transport. Geophys. Res. Lett. 42, 5661-5669. doi: 10.1002/2015GL064357

Zou, J., Shi, X., Liu, Y., Liu, J., Selvaraj, K., and Kao, S.-J. (2012). Reconstruction of environmental changes using a multi-proxy approach in the Ulleung Basin 
(Sea of Japan) over the last 48 ka. Journal of Quaternary Science 27, 891-900. doi: $10.1002 /$ jqs. 2578

Zou, J., Shi, X., Zhu, A., Chen, M.-T., Kao, S., Wu, Y., et al. (2015). Evidence of sea ice-driven terrigenous detritus accumulation and deep ventilation changes in the southern Okhotsk Sea during the last 180ka. Journal of Asian Earth Sciences 114, 541-548. doi: 10.1016/j.jseaes.2015. 07.020

Zou, J., Shi, X., Zhu, A., He, L., Kandasamy, S., Tiedemann, R., et al. (2021). Paleoenvironmental implications of $\mathrm{Sr}$ and $\mathrm{Nd}$ isotopes variability over the past $48 \mathrm{ka}$ from the southern Sea of Japan. Marine Geology 432, 106393. doi: 10.1016/j.margeo.2020.106393
Conflict of Interest: The authors declare that the research was conducted in the absence of any commercial or financial relationships that could be construed as a potential conflict of interest.

Copyright (c) 2021 Dou, Zou, Shi, Zhu, Dong, Gorbarenko, He, Gao, Zhang and Cui. This is an open-access article distributed under the terms of the Creative Commons Attribution License (CC BY). The use, distribution or reproduction in other forums is permitted, provided the original author(s) and the copyright owner(s) are credited and that the original publication in this journal is cited, in accordance with accepted academic practice. No use, distribution or reproduction is permitted which does not comply with these terms. 